\title{
Diversity and distribution of autotrophic microbial community along environmental gradients in grassland soils on the Tibetan Plateau
}

\author{
Guangxia Guo ${ }^{1}$ - Weidong Kong ${ }^{1}$ - Jinbo Liu ${ }^{1}$ - Jingxue Zhao ${ }^{2}$ Haodong Du ${ }^{1}$. \\ Xianzhou Zhang $^{3} \cdot$ Pinhua Xia ${ }^{1,4}$
}

Received: 14 April 2015 /Revised: 19 May 2015 / Accepted: 23 May 2015 / Published online: 18 June 2015

(C) Springer-Verlag Berlin Heidelberg 2015

\begin{abstract}
Soil microbial autotrophs play a significant role in $\mathrm{CO}_{2}$ fixation in terrestrial ecosystem, particularly in vegetation-constrained ecosystems with environmental stresses, such as the Tibetan Plateau characterized by low temperature and high UV. However, soil microbial autotrophic communities and their driving factors remain less appreciated. We investigated the structure and shift of microbial autotrophic communities and their driving factors along an elevation gradient (4400-5100 $\mathrm{m}$ above sea level) in alpine grassland soils on the Tibetan Plateau. The autotrophic microbial communities were characterized by quantitative PCR, terminal restriction fragment length polymorphism (T-RFLP), and cloning/ sequencing of $c b b L$ genes, encoding the large subunit for the
\end{abstract}

Electronic supplementary material The online version of this article (doi:10.1007/s00253-015-6723-x) contains supplementary material, which is available to authorized users.

Guangxia Guo

gxguo@itpcas.ac.cn

Weidong Kong

wdkong@itpcas.ac.cn

1 Key Laboratory of Alpine Ecology and Biodiversity, Institute of Tibetan Plateau Research, Chinese Academy of Sciences, Beijing 100101, China

2 Key Laboratory of Tibetan Environmental Changes and Land Surface Processes, Institute of Tibetan Plateau Research, Chinese Academy of Sciences, Beijing 100101, China

3 Key Laboratory of Ecosystem Network Observation and Modeling, Institute of Geographic Sciences and Natural Resources Research, Chinese Academy of Sciences, Beijing 100101, China

4 Guizhou Key Laboratory for Mountainous Environmental Information and Ecological Protection, Guizhou Normal University, Guiyang 550001, China
$\mathrm{CO}_{2}$ fixation protein ribulose-1,5-bisphosphate carboxylase/ oxygenase (RubisCO). High $c b b L$ gene abundance and high RubisCO enzyme activity were observed and both significantly increased with increasing elevations. Path analysis identified that soil RubisCO enzyme causally originated from microbial autotrophs, and its activity was indirectly driven by soil water content, temperature, and $\mathrm{NH}_{4}{ }^{+}$content. Soil autotrophic microbial community structure dramatically shifted along the elevation and was jointly driven by soil temperature, water content, nutrients, and plant types. The autotrophic microbial communities were dominated by bacterial autotrophs, which were affiliated with Rhizobiales, Burkholderiales, and Actinomycetales. These autotrophs have been well documented to degrade organic matters; thus, metabolic versatility could be a key strategy for microbial autotrophs to survive in the harsh environments. Our results demonstrated high abundance of microbial autotrophs and high $\mathrm{CO}_{2}$ fixation potential in alpine grassland soils and provided a novel model to identify dominant drivers of soil microbial communities and their ecological functions.

Keywords RubisCO $\cdot \mathrm{CO}_{2}$ fixation · Tibetan Plateau • Grassland $\cdot$ Elevation

\section{Introduction}

Tibetan Plateau is the highest plateau ( $>4000 \mathrm{~m}$ above sea level, a.s.l.) on the Earth. The plateau covers an area of $2.5 \times$ $10^{6} \mathrm{~km}^{2}$, and grassland is the dominant landscape. The plateau is characterized by low temperature, drought, and high solar radiation, which substantially constrain plant growth. The vulnerable ecosystems on the plateau are experiencing a rapid warming at a rate of $0.36{ }^{\circ} \mathrm{C}$ per decade (Wang et al. 2008), which is threefold the average global rate $\left(0.12^{\circ} \mathrm{C}\right)$ in the last 
50 years (1951-2012) (IPCC 2013 AR5, Climate Change 2013: The Physical Science Basis). Climate warming has accelerated glacier melting (Ding et al. 2006; Lutz et al. 2014) and changed vegetation phenology (Jin et al. 2013; Shen et al. 2014) on the plateau. A few recent studies have revealed that soil bacteria, archaea, ammonia oxidizers, and denitrifiers were sensitive to environmental changes and exhibited clear elevational patterns (Wang et al. 2015; Yang et al. 2014; Yuan et al. 2014; Zheng et al. 2014). However, as a global biodiversity hotspot, Tibetan Plateau receives less attention in soil functional microbial communities and their response to environmental changes, especially in autotrophic microbial communities.

Soil autotrophic microbial communities contribute significantly to carbon and nitrogen cycles in terrestrial ecosystems (Hart et al. 2013; Miltner et al. 2004; Selesi et al. 2005; Tolli and King 2005). Soil autotrophic microorganisms have been estimated to sequester up to $4.9 \mathrm{Pg} \mathrm{C}_{\mathrm{Cear}}{ }^{-1}$ in agricultural soils (Yuan et al. 2012a). In a semi-arid natural ecosystem, soil autotrophs have been observed to play an important role similar to plant vegetation in carbon sequestration (Su et al. 2013). This suggests that soil autotrophic microbial communities might play a significant role in $\mathrm{CO}_{2}$ fixation in extreme environments, e.g., Tibetan Plateau. Tibetan Plateau is a typical semi-arid/arid ecosystem, and its vegetation growth is critically constrained (Ren et al. 2010; Thomas et al. 2014). Soil autotrophic microbial community characteristics and their driving environmental factors on the plateau, however, remain largely unknown.

The Calvin-Benson-Bassham (CBB) cycle is the most widespread pathway for autotrophs to fix atmospheric $\mathrm{CO}_{2}$ on the Earth. The key enzyme in the CBB cycle is ribulose1,5-bisphosphate carboxylase/oxygenase (RubisCO), which catalyzes the first step in $\mathrm{CO}_{2}$ fixation. Four RubisCO forms (I, II, III, and IV) have been found, of which form I is the most abundant in nature (Tabita et al. 2008), and forms II, III, and IV are rarely detected in natural soils (Janatkova et al. 2013; $\mathrm{Wu}$ et al. 2014a). The large subunit of form I RubisCO is encoded by the $c b b L$ genes, which further divide form I RubisCO into four forms (IA, IB, IC, and ID) (Tabita et al. 2008). $c b b L$ genes encoding forms IA, IB, IC, and ID have been widely used as phylogenetic biomarkers to characterize biodiversity of autotrophic microorganisms in diverse habitats, e.g., oceans, lakes, and soils (John et al. 2007; Kong et al. 2012a, b; Yuan et al. 2012a).

The gradient of environmental factors along the elevations (4400-5100 m a.s.l.) on the Tibetan Plateau provides an important means to test how autotrophic microbial communities interact with environmental factors (Vetaas and Grytnes 2002; Yang et al. 2014; Zhang et al. 2009). We hypothesized that (1) high abundance of microbial autotrophs could occur in alpine grassland soils, for their high adaption in diverse harsh environments; (2) the autotrophic microbial community would change with elevation because of the change in environmental factors; and (3) different microbial autotrophs would differentially change with increasing elevations due to highly variable genetic backgrounds and metabolic characteristics. This study could provide fundamental knowledge on maintaining soil microbial diversity and the ecosystem services they underpin.

\section{Materials and methods}

\section{Site description and sample collection}

The study site is representative of a typical alpine grassland on the central Tibetan Plateau, China (Fig. S1). The vegetation and environmental factors in this location have been extensively investigated (Wang et al. 2012). Four plant species, Potentilla saundersiana (A), Saussurea japonica (B), Kobresia pygmaea (C), and Androsace umbellata (D), dominate these grasslands. The four plant species are typical alpine plants with low above-ground biomass and a short growth season (late May to September).

In September of 2012, soils were sampled from the southfacing slope of the Nyainqentanglha Mountains $\left(30^{\circ} 30^{\prime}-30^{\circ}\right.$ $\left.32^{\prime} \mathrm{N}, 91^{\circ} 03^{\prime} \mathrm{E}\right)$ in replicates of three at five elevations ( 4400 , 4650, 4800, 4950, and $5100 \mathrm{~m}$ ) (designated E1, E2, E3, E4, and E5, respectively). Depending on the elevation, there were three or four plant species in the sampling area. At each replicate site, three soil cores $(0-10 \mathrm{~cm}$ in depth) were collected and mixed. Soil samples were transported to the laboratory in coolers with ice bags and then passed through a $2.0-\mathrm{mm}$ soil sieve. Subsamples taken for DNA extraction and RubisCO enzyme activity assay were stored at $-80{ }^{\circ} \mathrm{C}$, and the remaining soils were air dried for soil physicochemical analyses.

\section{Soil physicochemical factor analysis}

Soil factors were measured using standard methods (Tan 2005). (1) Soil water content (SWC) was gravimetrically determined after drying at $105{ }^{\circ} \mathrm{C}$ for $12 \mathrm{~h}$, (2) soil pH was determined using a soil to water ratio of $1: 2.5$ by a $\mathrm{pH}$ meter (Sartorius PB-10, Germany), (3) soil nitrate $\left(\mathrm{NO}_{3}{ }^{-}\right)$and ammonium $\left(\mathrm{NH}_{4}^{+}\right)$were extracted with $1 \mathrm{M} \mathrm{KCl}$ and determined using an Automated Discrete Analyzer (AQ2+, SEAL Analytical Inc., England), (4) total organic carbon (TOC) was measured in the solid state using a TOC analyzer (TOCVCPH, Shimadzu, Japan), (5) soil temperature $(0-10 \mathrm{~cm}$ in depth, September of 2012) was recorded at 30-min intervals by HOBO weather stations (Onset Inc., Bourne, MA, USA) at each elevation.

\section{DNA extraction}

Total DNA was extracted from $0.5 \mathrm{~g}$ fresh soil using the Fast DNA SPIN kit for soil (BIO101, USA) following the 
manufacturer's instructions. The purity and quantity of the DNA were determined using a NanoDrop ND-1000 spectrophotometer (NanoDrop Technologies Inc., Wilmington, DE, USA).

\section{Real-time quantitative PCR}

Form IA/B, IC, and ID $c b b L$ genes were quantified using primer sets cbbLG-1F/cbbLG-1R (Selesi et al. 2005), IC-F/ IC-R (Alfreider et al. 2009), and ID-F/ID-R (Paul et al. 2000), respectively, using a LightCycler480 (Roche Diagnostics Ltd, USA). These primer sets were designed to specifically target microbial autotrophs in diverse environments and exclude those from plants. Standard curves were made using plasmid clones of target gene fragments specific to each $c b b L$ gene. Quantitative PCR (qPCR) was conducted using the Takara SYBR green kit (SYBR ${ }^{\circledR}$ Premix Ex Taq ${ }^{\mathrm{TM}}$ GC, Takara Biotechnology Co., Ltd., China) with a temperature program of denaturation at $94^{\circ} \mathrm{C}$ for $5 \mathrm{~min}$ and followed by 35 cycles of $30 \mathrm{~s}$ at $94^{\circ} \mathrm{C}, 30 \mathrm{~s}$ at $58^{\circ} \mathrm{C}$ (for IA/B), $52^{\circ} \mathrm{C}$ (for IC) or $54^{\circ} \mathrm{C}$ (for ID), and $30 \mathrm{~s}$ at $72{ }^{\circ} \mathrm{C}$, and fluorescence intensity was acquired at $72{ }^{\circ} \mathrm{C}$. The qPCR efficiencies of the three genes were $90.7-104.2 \%$ with $R^{2}$ values more than 0.995 . Melting curve analysis $\left(50\right.$ to $95^{\circ} \mathrm{C}$ ) and agarose gel electrophoresis were performed at the end of qPCR to check the specificity of amplification.

\section{Terminal restriction fragment length polymorphism analysis}

The microbial community structures of IC and ID $c b b L$ carrying populations were determined using terminal restriction fragment length polymorphism (T-RFLP) profiles. We could not obtain enough PCR product yields for form IA/B T-RFLP profile screening due to low IA/B $c b b L$ abundance. PCR was performed in triplicate for each soil sample using the above primer sets that target the form IC and ID $c b b L$ genes. All the forward primers were labeled with 6-carboxy-fluorescein (FAM) at the $5^{\prime}$ end. The PCR was conducted using Takara Master Mix and amplified using a program of 25 cycles of $94{ }^{\circ} \mathrm{C}$ for $1 \mathrm{~min}, 52^{\circ} \mathrm{C}$ (for IC) or $54^{\circ} \mathrm{C}$ (for ID) for $1 \mathrm{~min}$, and $72^{\circ} \mathrm{C}$ for $1 \mathrm{~min}$. The labeled PCR product with target fragment was run on an agarose gel; the band was cut from the gel and purified (Axygen, CA, USA), and then digested at $37^{\circ} \mathrm{C}$ for $5 \mathrm{~h}$ using the restriction enzymes $M s p I$ (for IC) and AluI (for ID). Digestion products were purified using Sigma Spin Post Reaction Clean-Up columns (Sigma, USA), and a portion was mixed with deionized formamide and the internal standard GeneScan-1000 LIZ (Applied Biosystems, USA). The mixtures were denatured for $3 \mathrm{~min}$ at $95{ }^{\circ} \mathrm{C}$, and the DNA fragments were size separated using a 3130xl Genetic Analyzer (Applied Biosystems, USA).
T-RFLP profiles of each sample were analyzed using GeneScan analysis software (Applied Biosystems, USA). The peak areas of the terminal restriction fragments (T-RFs) that differed by $\pm 1 \mathrm{bp}$ were summed and considered to be one fragment. The relative abundance (RA) of each T-RF was calculated as described by Lukow et al. (2000). Only T-RFs with the RA $>1 \%$ in all three replicates were included for further analysis, and fragments with RA $>10 \%$ were regarded as dominant T-RFs (Yuan et al. 2012b). Absolute abundance (AA) of each T-RF was calculated based on relative abundance of each T-RF and qPCR data. To assign phylogenetic affiliation to specific T-RFs, the operational taxonomic unit (OTU) sequences generated from clone libraries (see below) were subjected to in silico analysis based on the enzyme site of $M s p I\left(\mathrm{C}^{\wedge} \mathrm{CGG}\right)$ for form IC and $\mathrm{AluI}\left(\mathrm{AG}^{\wedge} \mathrm{CT}\right)$ for form ID.

\section{Cloning, sequencing, and phylogenetic analysis}

To further identify the autotrophic microbes associated with the T-RFs, clone libraries were generated from four soils (E1B, E2A, E2C, and E4C) for the form IC $c b b L$ gene and from two soils (E2C and E4C) for the form ID $c b b L$ gene. The six clone libraries contained all the unique T-RFs. PCR amplification was performed using the same primers, without the fluorescent labels. Subsequently, PCR products were purified with a DNA gel extraction kit (Axygen, CA, USA), ligated into the pGEM-T Easy Vector (Promega, Madison, USA), and then transformed into Escherichia coli JM109 competent cells. Positive clones were screened through the reamplification with the vector-specific primers M13F and M13R. For each clone library of form IC and ID, about 90 positive clones were randomly sequenced.

Multiple sequence alignments were performed using CLUSTALW in MEGA6.0 (Tamura et al. 2013). Sequences with the nucleotide similarity $>97 \%$ were defined as an OTU using the Mothur program v.1.33.3 (Schloss et al. 2009). BLASTn (www.ncbi.nlm.nih.gov/BLAST/) was employed to search GenBank for the nearest related sequences to each OTU. Phylogenetic trees were constructed using the neighbor-joining method with the maximum composite likelihood model using MEGA6.0 (Tamura et al. 2013). The reliability of phylogenetic trees was tested using bootstrap with 1000 iterations. Sequences generated in this study have been deposited in the National Center for Biotechnology Information GenBank database under accession numbers KM433867 to KM433891 for form ID and KM433892 to KM433998 for form IC.

\section{RubisCO enzyme activity assay}

Freeze-wet soils ( $5.0 \mathrm{~g}$ dry weight) were washed with TENPPVPP buffer ( $\mathrm{pH}$ 10.0) for four times to remove extracellular free proteins, humic acid and fulvic acid, which affect the enzyme measuring. Then, PBS (0.01 M, pH 7.4) and sterile 
ultra clean water were successively used to balance the osmotic pressure and remove the inorganic salt ions. After the above pretreatment, the cleaned precipitate was freeze-dried using a vacuum freezing drier and then for extraction of total protein by ultrasonication in an ice bath (Takai et al. 2005; Wu et al. 2014b). Enzyme activity was measured at $30^{\circ} \mathrm{C}$ by the spectrophotometer method $(340 \mathrm{~nm})$ using an ELISA reader (MULTISKAN ASCENT, Thermo Fisher Scientific, USA). Following the addition of substrate $(25 \mathrm{mM}$ ribulose bisphosphate), absorbance was read every $30 \mathrm{~s}$. All reactions were carried out in triplicate, and negative controls (the absence of ribulose bisphosphate and the presence of heatdenatured protein extracts) were used. RubisCO enzyme activity (nmol $\mathrm{CO}_{2} \mathrm{~g}^{-1}$ soil $\mathrm{min}^{-1}$ ) was calculated as described by Yuan et al. (2012a).

\section{Statistical analysis}

Box plots were generated using Sigmaplot 12.5 (Systat Software, Inc., San Jose, CA, USA). Relationships between $c b b L$ gene abundance and environmental factors were determined using Pearson correlation in SPSS 21.0 (Armonk, NY). All soil physicochemical factors were standardized by $Z$ transformation (overall mean of 0 and SD of 1) prior to statistical analysis. To visualize the distribution pattern of soil autotrophic microbial communities along the elevation gradient, the relative abundance of all T-RFLP peaks was used for ordination analysis using CANOCO 5 (Microcomputer Power, Ithaca, NY). Prior to the ordination analysis, the longest gradient (LG) was calculated using detrended correspondence analysis for ordination method selection. LG less than 3.0 indicates that the community data are more specifically suited for analysis using a liner model (redundancy analysis, RDA); otherwise, a unimodal model method is more appropriate (canonical correspondence analysis, CCA). Thus, form IC communities were subjected to CCA, and form ID was subjected to RDA. The relationships of IC, ID T-RFLP patterns, and the $c b b L$ gene abundance (IA/B, IC, and ID) with all soil and vegetation factors ( $\mathrm{pH}, \mathrm{TOC}, \mathrm{NH}_{4}{ }^{+}, \mathrm{NO}_{3}{ }^{-}$, $\mathrm{SWC}$, soil temperature, and plant type) were calculated using the built-in manual forward selection in CANOCO 5. Only factors that passed the Monte Carlo permutation test $(p<0.05$ or VIF $<20)$ were included for further analysis. Furthermore, variation partition analysis (VPA) was performed to determine the individual contribution of each environmental factor by partitioning the effect of co-correlated factors on the microbial community variation using CANOCO 5 (Guo et al. 2013a).

A structural equation model (SEM) was constructed using AMOS 21.0 (SPSS Inc., Armonk, NY) to determine how soil RubisCO enzyme activity was driven by soil factors and autotrophic microbial community. The $c b b L$ gene abundance was integrated by summing the qPCR numbers of forms IA/ $\mathrm{B}$, IC, and ID. The maximum likelihood relative chi-square goodness-of-fit test (CMIN/DF), Jöreskog's goodness-of-fit index (GFI), root mean square error of approximation (RMSEA), and the Bollen-Stine bootstrap test (high $p$ values indicate that the data fit the model well) were used to test fitness of the model with the data. Models with CMIN/DF less than 4, GFI greater than 0.9, and RMSEA less than 0.08 were chosen. A comparative fit index (CFI) was used to compare alternative nested models, and the CFI values ranged from 0 to 1 and greater than 0.95 was considered an acceptable model (Shipley 2000).

\section{Results}

\section{Soil physicochemical factors along the elevation gradient}

All the tested factors significantly changed with increasing elevations. Soil temperature (T_10) dramatically decreased from $9.7^{\circ} \mathrm{C}$ at $4400 \mathrm{~m}$ to $5.8^{\circ} \mathrm{C}$ at $5100 \mathrm{~m}$, soil $\mathrm{pH}$ decreased from 7.0 to 5.3 , and $\mathrm{NO}_{3}{ }^{-}$decreased from 0.8 to $0.3 \mathrm{mg} \mathrm{kg}^{-1}$ dry soil (Table S1) with increasing elevations. Reverse to the above factors, soil water content (SWC, 9.8-81.4\%), total organic carbon (TOC, 1.6-10.1\%), and $\mathrm{NH}_{4}{ }^{+}(2.1-$ $23.4 \mathrm{mg} \mathrm{kg}^{-1}$ dry soil) increased with elevation up to $4900 \mathrm{~m}$ and remained constant at $5100 \mathrm{~m}$. Pearson correlations demonstrated that elevation negatively correlated with soil temperature, $\mathrm{pH}$, and $\mathrm{NO}_{3}{ }^{-}$but positively correlated with SWC, TOC, and $\mathrm{NH}_{4}^{+}(p<0.01$, Table S2).

\section{Abundance of $c b b L$ genes and RubisCO enzyme activity along the elevation gradient}

The abundance of different forms of $c b b L$ genes (IA/B, IC, and ID) was quantified using qPCR and primer sets specifically designed to target autotrophic microbes. The $c b b L$ gene abundance ranged from $10^{4}$ to $10^{6}$ copies $\mathrm{g}^{-1}$ dry soil for form $\mathrm{IA} / \mathrm{B}, 10^{7}$ to $10^{9}$ copies $\mathrm{g}^{-1}$ dry soil for IC, and $10^{6}$ to $10^{7}$ copies $\mathrm{g}^{-1}$ dry soil for ID (Fig. 1a). Form IC $c b b L$ abundance substantially outnumbered ID and IA/B by 100 -fold and 500 fold, respectively. Therefore, form IC microbial autotrophs dominated soil autotrophic community in the alpine grassland soils. The abundance of forms IA/B and IC $c b b L$ genes significantly increased along the elevation gradient and exhibited a significant positive correlation with elevation $(p<0.01$, Table S2). The gene abundance of IA/B and IC positively correlated with SWC, TOC, and $\mathrm{NH}_{4}^{+}$, but negatively correlated with soil temperature and $\mathrm{pH}(p<0.01)$.

Similar to the trend of IA/B and IC $c b b L$ gene abundance, RubisCO enzyme activity significantly increased from 4650 to $4800 \mathrm{~m}$ (Fig. 1b), ranging from 5.4 to $24.5 \mathrm{nmol} \mathrm{CO}_{2} \mathrm{~g}^{-1}$ dry soil $\mathrm{min}^{-1}$. The enzyme activity positively correlated with elevation, gene abundance of forms IA/B and IC, TOC, $\mathrm{NH}_{4}{ }^{+}$, 

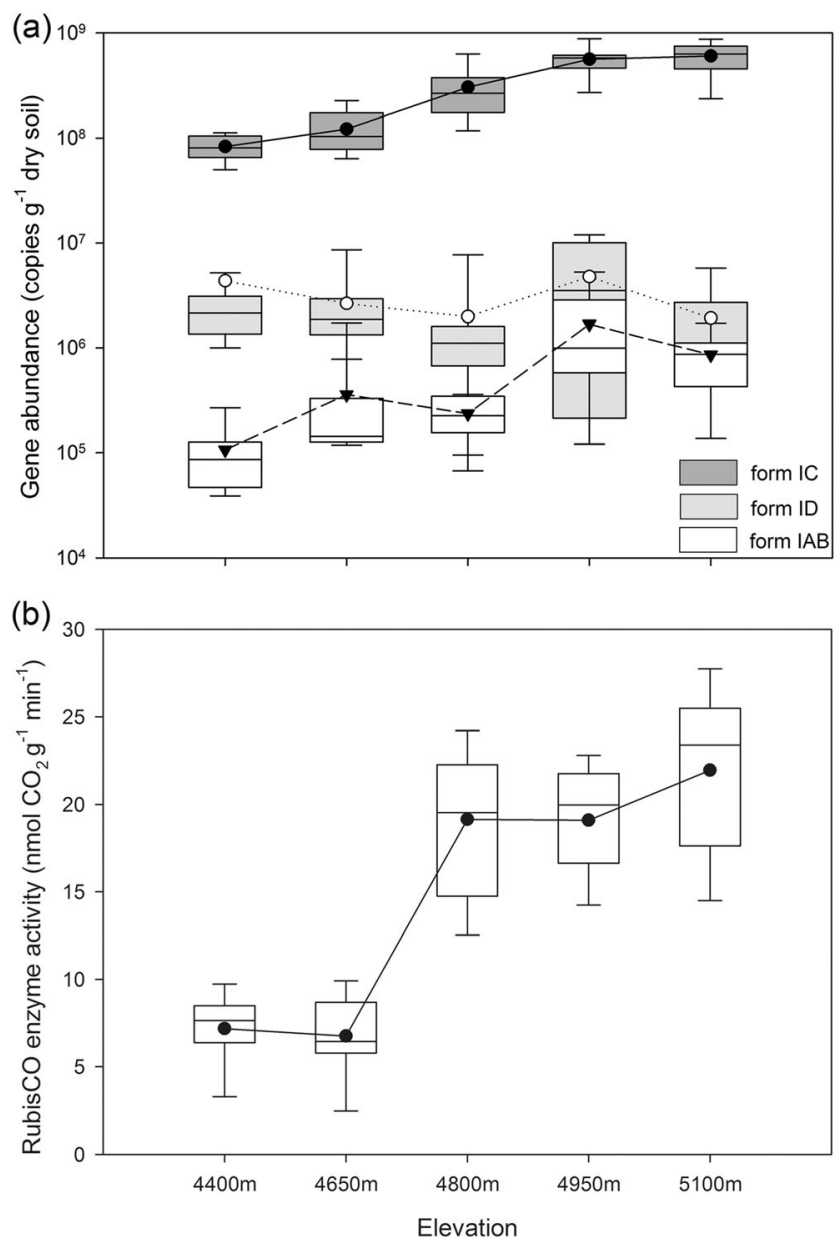

Fig. 1 Changes in the abundance of $c b b L$ genes (form IA/B, IC, and ID) (a) and RubisCO enzyme activity (b) in alpine grassland soils along the elevation gradient. In the box plots, the symbols indicate the following: box 25 th to 75 th percentile, horizontal line median, whiskers minimum and maximum values. Points and down triangles represent the average values

and SWC $(p<0.05)$, but negatively correlated with soil $\mathrm{pH}$ and temperature $(p<0.001$, Table S2).

\section{Analysis of soil autotrophic microbial community structure}

The soil autotrophic community structure based on T-RFLP profiles was analyzed by ordination analysis. A total of $16 \mathrm{~T}-$ RFs for IC community and 21 T-RFs for ID community were observed. The pattern of IC communities exhibited a gradual change from 4400 to $5100 \mathrm{~m}$ and a greater variation occurred in the transitions from 4400 to $4650 \mathrm{~m}$ and from 4800 to $4950 \mathrm{~m}$. CCA revealed that IC community structure was jointly driven by soil physicochemical factors (temperature, SWC, TOC, $\mathrm{NO}_{3}^{-}, \mathrm{NH}_{4}^{+}, \mathrm{pH}$ ) and plant type (Fig. 2a). These factors jointly explained $53.4 \%(p<0.001)$ of IC community variation, and soil temperature, SWC, and TOC were three dominant factors which explained $33.7,33.4$, and $28 \%$ of the (a)

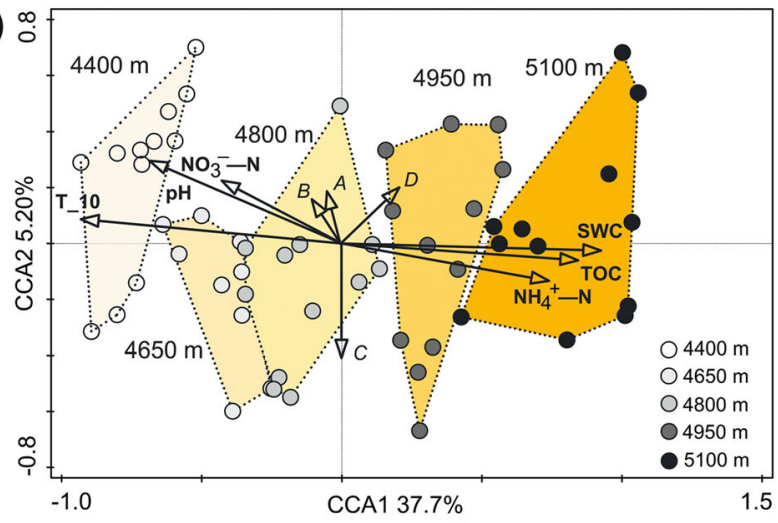

(b)

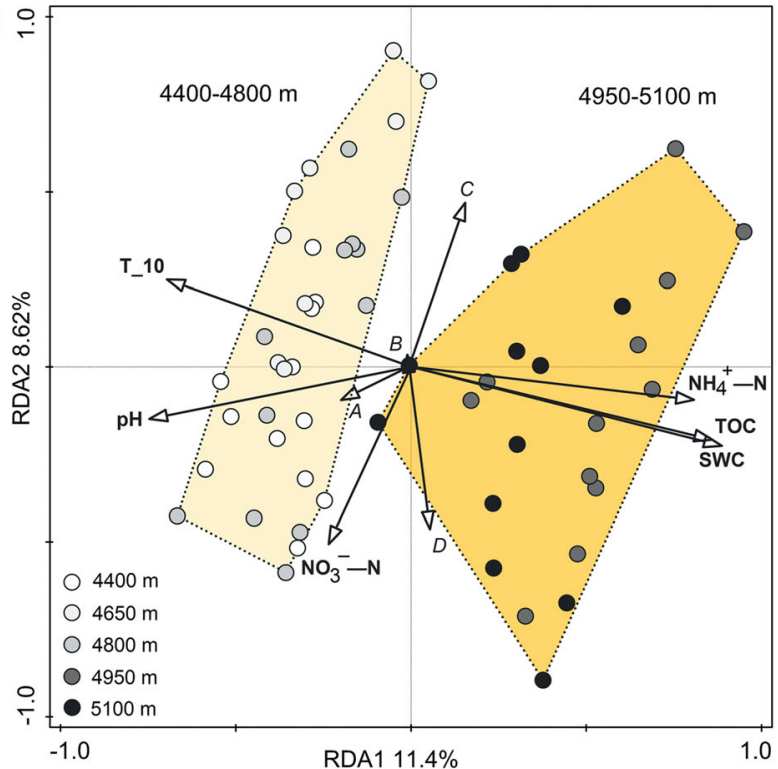

(c)

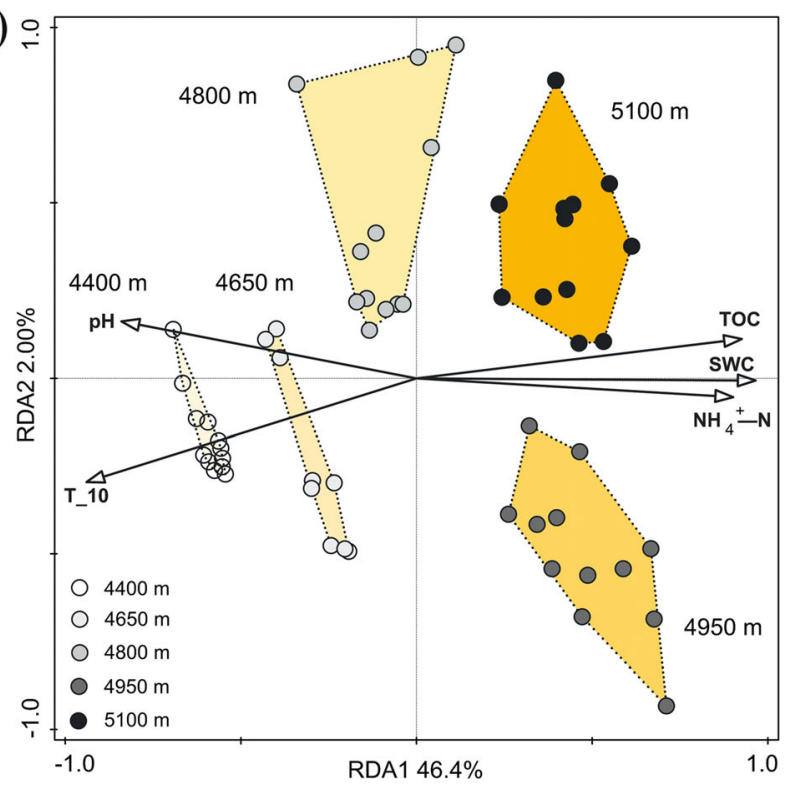

Fig. 2 Ordination plots of T-RFLP profiles for form IC (a canonical correspondence analysis) and form ID (b redundancy analysis) autotrophic microbial community structure and $c b b L$ gene abundance pattern (c redundancy analysis). A, Potentilla saundersiana; $B$, Saussurea japonica; $C$, Kobresia pygmaea; $D$, Androsace umbellata 
variation, respectively (Table 1). After partitioning the effect of co-correlated factors, VPA further indicated that soil temperature could individually explain $6.4 \%$ of the IC community variation, while SWC and plant type individually explained 4.0 and $4.4 \%$, respectively. Thus, the variation of IC autotrophic community structure was jointly driven by multiple factors but not by individual factor.

Redundancy analysis (RDA) revealed that ID community structure also displayed a significant difference between low elevations (4400-4800 m) and high elevations (4900-5100 m) (Fig. 2b). The ID community structure variation could be jointly explained by all environmental factors $(34.2 \%, p<0.001)$, and plant type $(15.3 \%)$, SWC $(10.1 \%)$, and temperature $(7.6 \%)$ were dominant factors (Table 1) affecting the variation. VPA exhibited that the three dominant factors individually explained $10.3,3.10$, and $4.10 \%$ of the ID variation, respectively.

Given co-occurrence of the three forms of $c b b L$ gene (IA/B, IC, and ID) in soils, abundance of the three $c b b L$ genes was subjected to an ordination plot. The overall gene abundance pattern exhibited a gradual shift with the elevation and soil factors significantly correlated with the shift (Fig. 2c). Approximately half $(48.6 \%, p<0.001)$ of the variation in gene abundance pattern could be jointly explained by environmental factors except $\mathrm{NO}_{3}{ }^{-}$(Fig. 2c and Table 1). VPA revealed that the variation was individually explained by SWC (5.9 \%), soil temperature (4.2\%), and $\mathrm{NH}_{4}^{+}(4.9 \%)$ (Table 1$)$.

\section{Variations of specific T-RFs with elevation and identification of microbial autotrophs}

Of the total 16 unique T-RFs in form IC microbial autotrophs, 4 T-RFs $(84,120,273$, and $340 \mathrm{bp})$ were dominant (Fig. 3a). The most striking was a significant decrease of TRF 84 bp $(R=-0.605, p<0.001)$ in relative abundance and a significant increase of the T-RFs 120 bp $(R=0.494$, $p<0.001)$ and $273 \mathrm{bp}(R=0.737, p<0.001)$ with increasing elevations (Fig. S3a). The absolute abundance of the first 3 dominant T-RFs (except $340 \mathrm{bp}$ ) significantly increased along the increasing elevation and positively correlated with elevation when combining the relative abundance with the qPCR results (Fig. S3c). Clone libraries were constructed for selected soil samples with different dominant T-RFs, and sequencing analysis was conducted to assign phylogenetic affiliation to specific T-RFs. The form IC $c b b L$ sequences were phylogenetically affiliated with 13 unique groups, belonging to three categories: Alphaproteobacteria (groups I to VIII), Betaproteobacteria (groups IX and X), and Actinobacteria (groups XI, XII, and XIII) (Fig. 4). The T-RF 84 bp represented Alphaproteobacteria (Bradyrhizobium, Mesorhizobium, Starkeya novella, and Rhizobium), Betaproteobacteria (Variovorax and Rubrivivax), and Actinobacteria (Thermomonospora). The T-RF 120 bp represented Betaproteobacteria (Variovorax), Alphaproteobacteria, and Actinobacteria. The T-RF $273 \mathrm{bp}$ was putatively indentified as Actinobacteria and Alphaproteobacteria (Bradyrhizobium, Rhizobium, and

Table 1 Contributions of each environmental factor on the abundance and structure of soil autotrophic microbial communities

\begin{tabular}{|c|c|c|c|c|}
\hline \multicolumn{2}{|l|}{ Environmental factors } & \multicolumn{3}{|c|}{ Individual contribution of each factor ( $\%$ variation $)^{\mathrm{a}}$} \\
\hline \multirow[t]{2}{*}{ Factor group } & \multirow[t]{2}{*}{ Specific factors } & \multicolumn{2}{|l|}{ Community structure } & \multirow{2}{*}{$\begin{array}{l}c b b L \text { gene abundance } \\
\text { Form IC, ID, and IAB }\end{array}$} \\
\hline & & IC & ID & \\
\hline \multirow[t]{4}{*}{ Chemical factors } & Total organic carbon (TOC) & $28.00 * *(1.10)$ & $9.60 * * *(0.90)$ & $39.80^{* * *}(0.20)$ \\
\hline & $\mathrm{NO}_{3}^{-}$ & $8.80 * *(2.50) *$ & $4.30 *(2.80)$ & \\
\hline & $\mathrm{NH}_{4}^{+}$ & $21.90 * *(1.70)$ & $8.20 * *(2.50)$ & $37.70 * * *(4.90) *$ \\
\hline & $\mathrm{pH}\left(\mathrm{H}_{2} \mathrm{O}\right)$ & $20.00 * *(3.10)^{* *}$ & $7.60 * *(2.10)$ & $32.80 * * *(1.10)$ \\
\hline \multirow[t]{2}{*}{ Hydrothermal factors } & Soil water content (SWC) & $33.40 * *(4.70)^{* * *}$ & $10.10 * * *(3.10)^{* *}$ & $43.20 * * *(5.90) *$ \\
\hline & Soil temperature $\left(T_{-} \_\right.$10) & $33.70 * *(6.40)^{* *}$ & $7.60 * * *(4.10)^{* *}$ & $41.10 * * *(4.20) *$ \\
\hline Vegetation & Plant types & $9.70 * *(4.40)^{* *}$ & $15.30 * *(10.3) * *$ & \\
\hline Total explained $(\%)$ & & $53.40 * * *$ & $34.20 * * *$ & $48.60 * * *$ \\
\hline
\end{tabular}

CCA and corresponding variation partitioning analyses (VPA) tested the correlation between T-RFLP data of form IC $c b b L$ genes and environmental factors. RDA and corresponding VPA were used to test correlations between environmental factors and the T-RFLP profiles of form ID $c b b L$ genes or the gene copy number abundance data (forms IC, ID, and IAB)

${ }^{\text {a }}$ The numbers outside of brackets represent the contribution of each environmental variable for the variation of the abundance or structure of the autotrophic microbial communities in the CCA or RDA. The numbers inside brackets represent the respective contribution of each environmental variable with partitioning the effect of other variables in the VPA

Significance was determined by the Monte Carlo test with 1000 permutations ${ }^{*} p<0.05$; ${ }^{* *} p<0.01 ;{ }^{* * *} p<0.001$ and missing values indicate nonsignificant correlation $(p \geq 0.05)$ 
Fig. 3 T-RFLP patterns of autotrophic microbial community for form IC (a) and for form ID (b). Errors bars represent standard errors of triplicate samples. $E 1$ to $E 5$ represent the elevations 4400, 4650, 4800, 4950, and $5100 \mathrm{~m}$ and $A$ to $D$ represent the vegetation Potentilla saundersiana, Saussurea japonica, Kobresia pygmaea, and Androsace umbellata, respectively
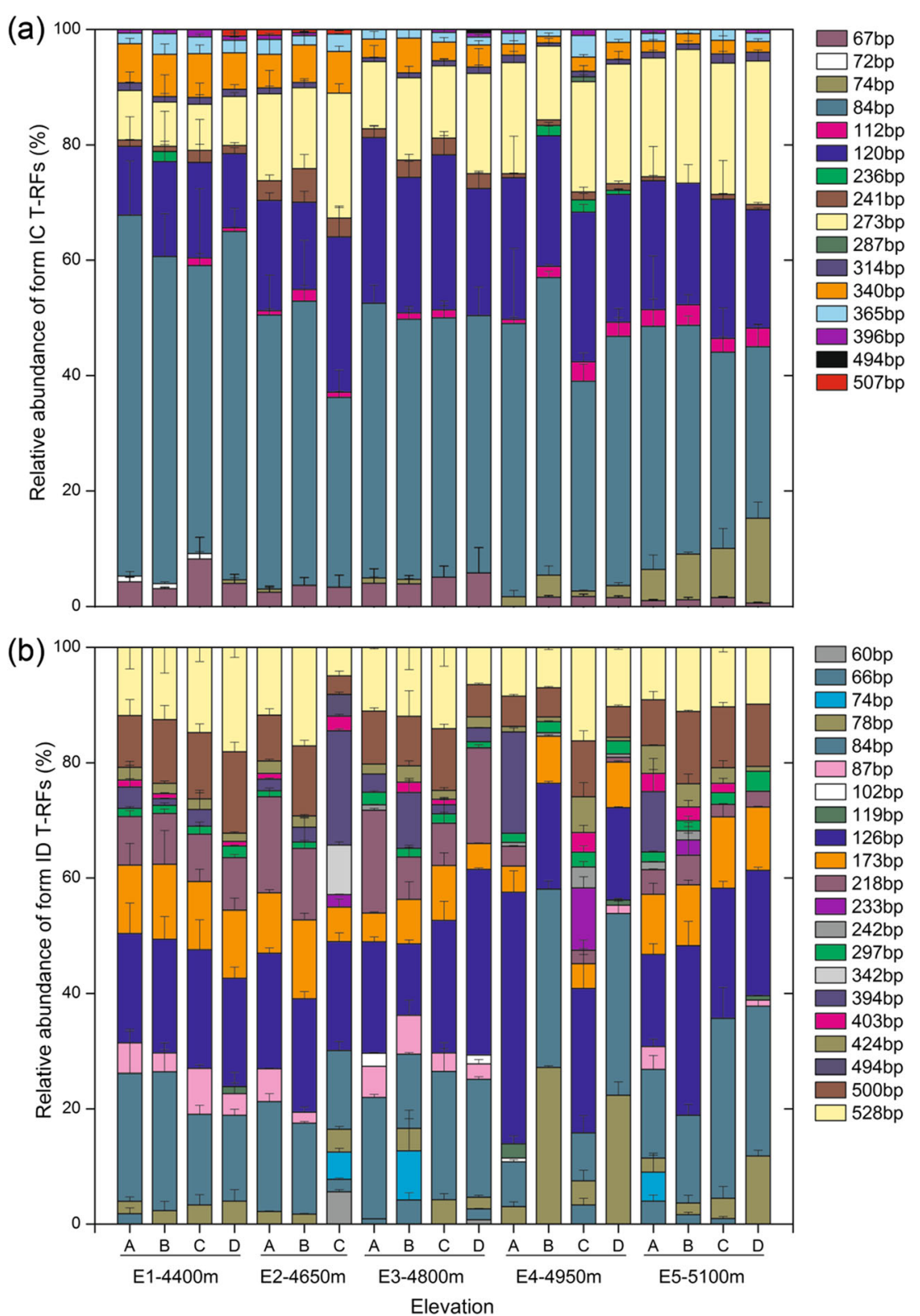

Mesorhizobium). The 340 bp T-RF only represented Thermomonospora belonging to Actinobacteria.

ID T-RFLP profiles demonstrated that $4(84,126,173$, and $528 \mathrm{bp}$ ) of 21 T-RFs dominated in all soils (Fig. 3a). The TRFs 126 and 84 bp exhibited large variations and kept relatively constant along the elevations. The relative abundance of T-RFs 173,218 , and 528 bp significantly decreased with increasing elevations $(R=-0.277 ; R=-0.465 ; R=-0.354)$ (Fig. S3b). Contrarily, the absolute abundance of T-RF $218 \mathrm{bp}$ significantly decreased with increasing elevations when combining the relative abundance with qPCR results (Fig. S3d). The ID sequences fell into four groups, Actinobacteria, Cyanobacteria, Haptophyta, and Heterokontophyta (Fig. S2). The in silico analysis exhibited that these sequences were assigned to $10 \mathrm{~T}-\mathrm{RF}$. The T-RFs 84 and $126 \mathrm{bp}$ represented Heterokontophyta, including Fragilaria crotonensis and Stephanodiscus sp., while T-RFs 173 and 528 bp both represented Actinobacteria. The T-RF 218 bp was assigned to Chrysochromulina parva (AB043694) of Haptophyta.

\section{RubisCO enzyme activity change and the effects of environmental factors}

Structural equation model (SEM) was used to determine the causal relationship among RubisCO enzyme activity, autotrophic microbial community, and environmental factors (Fig. 5). RubisCO enzyme activity was directly driven by $c b b L$ gene 
Fig. 4 Neighbor-joining phylogenetic tree of representative form IC $c b b L$ gene sequences retrieved from environmental DNA from the alpine grassland soils on the Tibetan Plateau. The tree was separated into

Alphaproteobacteria (a) and Betaproteobacteria and

Actinobacteria (b). The name of soil sample was named as the start of clone names $(E 1,4400 \mathrm{~m} ; E 2$, $4650 \mathrm{~m} ; E 4,4950 \mathrm{~m} ;$ A, Potentilla saundersiana; $B$, Saussurea japonica; $C$, Kobresia pygmaea), followed by the clone number. The respective sizes of T-RFs after in silico analysis with $M s p I$ and the GenBank accession number were listed in brackets (a)

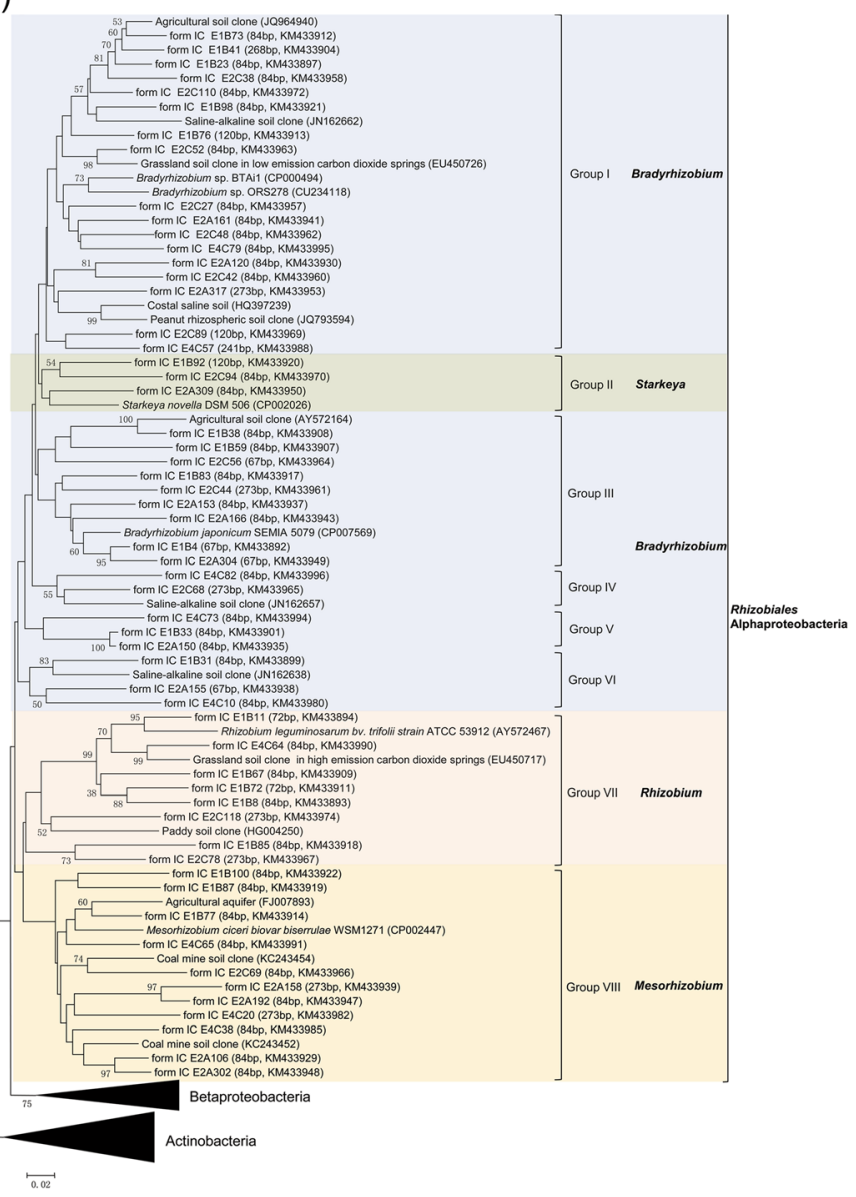

(b)

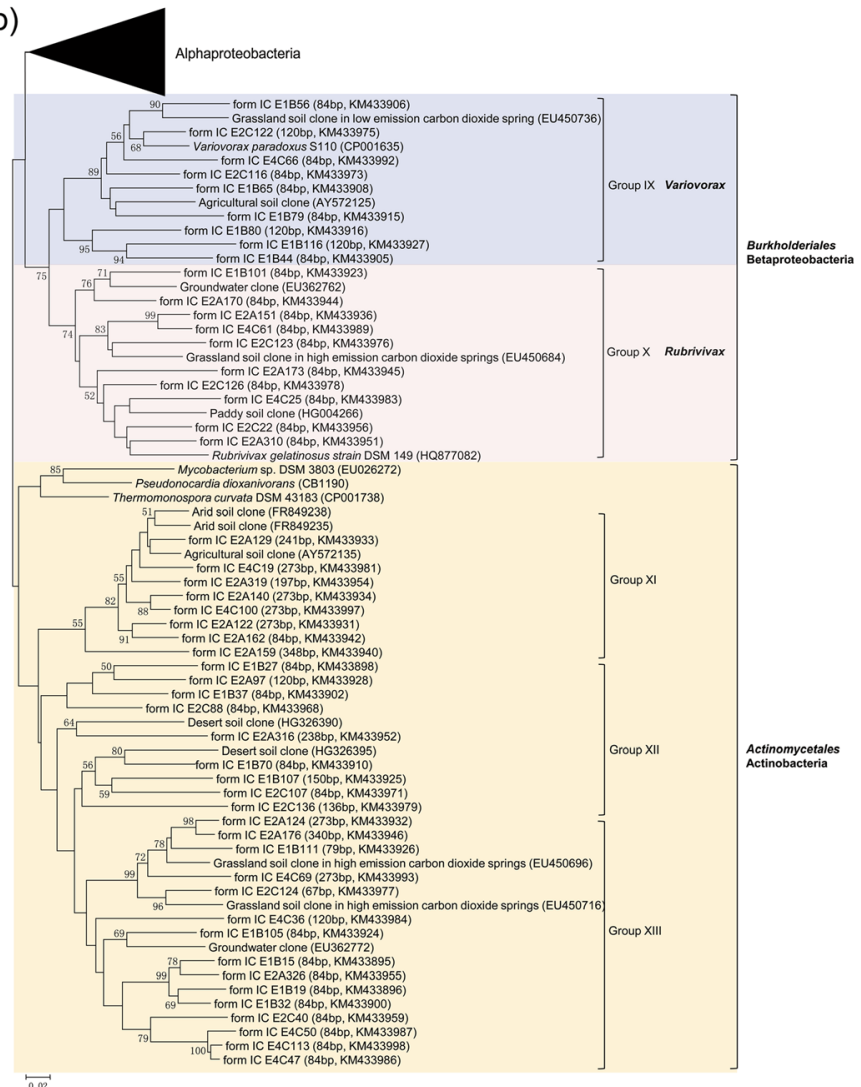


abundance $(p<0.001)$, and $71 \%$ of the variation was explained by the latter (Fig. 5 and Table S3), confirming the concept that soil RubisCO enzyme is only from microbial autotrophs but not from plants. In contrast, RubisCO enzyme activity was indirectly driven by environmental factors. Through the $c b b L$ gene abundance, RubisCO enzyme activity was indirectly increased by soil $\mathrm{NH}_{4}{ }^{+}(p<0.001)$ and water content $(p<0.01)$, but indirectly decreased by soil temperature $(p<0.05)$. Soil $\mathrm{pH}$ and TOC failed to exhibit a significant effect on $c b b L$ gene abundance and RubisCO enzyme activity.

\section{Discussion}

Elevation usually encompasses primary change in climatic conditions (temperature and precipitation) and consequently results in a corresponding change in vegetation and soil physicochemical factors (Guo et al. 2013b; Nogues-Bravo et al. 2008; Wang et al. 2013). At this study site of the Tibetan Plateau, higher elevation exhibited higher precipitation and lower temperature, which consequently induced higher plant growth (Wang et al. 2013), soil water content and nutrients (TOC and $\mathrm{NH}_{4}{ }^{+}$), but lower soil $\mathrm{pH}$ (Table $\mathrm{S} 1$ ). It is reasonable to assume that the higher nutrients at higher elevations result from enhanced plant biomass (above and below ground) (Wang et al. 2013). This gradient of plant and soil factors along the elevation provides an opportunity to explore the interaction of soil microbial communities and their ecological functions with environmental factors.

High levels of $c b b L$ gene abundance and RubisCO enzyme activity were observed in this study (Fig. 1), suggesting a significant potential in microbial $\mathrm{CO}_{2}$ fixation in alpine grassland soils. Compared with grassland soils (Videmšek et al. 2009) and high-productivity agricultural soils (Ge et al. 2012; Xiao et al. 2014a, b; Yuan et al. 2012a), alpine grassland soils exhibited similar or even higher $c b b L$ gene abundance and RubisCO enzyme activity. In paddy and upland agricultural soils, microbial autotrophs could account for up to $0.59 \%$ of soil organic matter (Wu et al. 2014a; Yuan et al. 2012a). Given the widespread of autotrophic microorganisms in extreme environments (Elsaied and Naganuma 2001; Kong et al. 2012a; Nanba et al. 2004; Xu and Tabita 1996), our finding highlights the important role of microbial autotrophs in alpine grassland soils where plant growth is dramatically constrained by low temperatures and high irradiance.

The $c b b L$ gene abundance and RubisCO enzyme activity significantly increased with increasing elevations (Fig. 1b). Similar altitudinal trend was observed in denitrification population abundance (nirS and nosZ) on the Tibetan Plateau (Yang et al. 2014). A significant causal relationship was revealed by SEM and further exhibited that soil RubisCO enzyme activity is only derived from microbial autotrophs and is indirectly increased by $\mathrm{NH}_{4}{ }^{+}$and soil water content, but indirectly decreased by temperature (Fig. 5 and Table S3). Assuming that microbes, including microbial autotrophs, are usually constrained by lower temperature, the coincidence of higher autotroph abundance and lower temperature at higher elevations indicates that these autotrophs could endure or have adapted to lower temperature. Water content and $\mathrm{NH}_{4}{ }^{+}$offset the inhibitory effect of lower temperature on microbial autotrophs and their enzyme activity. Microbial autotroph abundance and their enzyme activity were not significantly

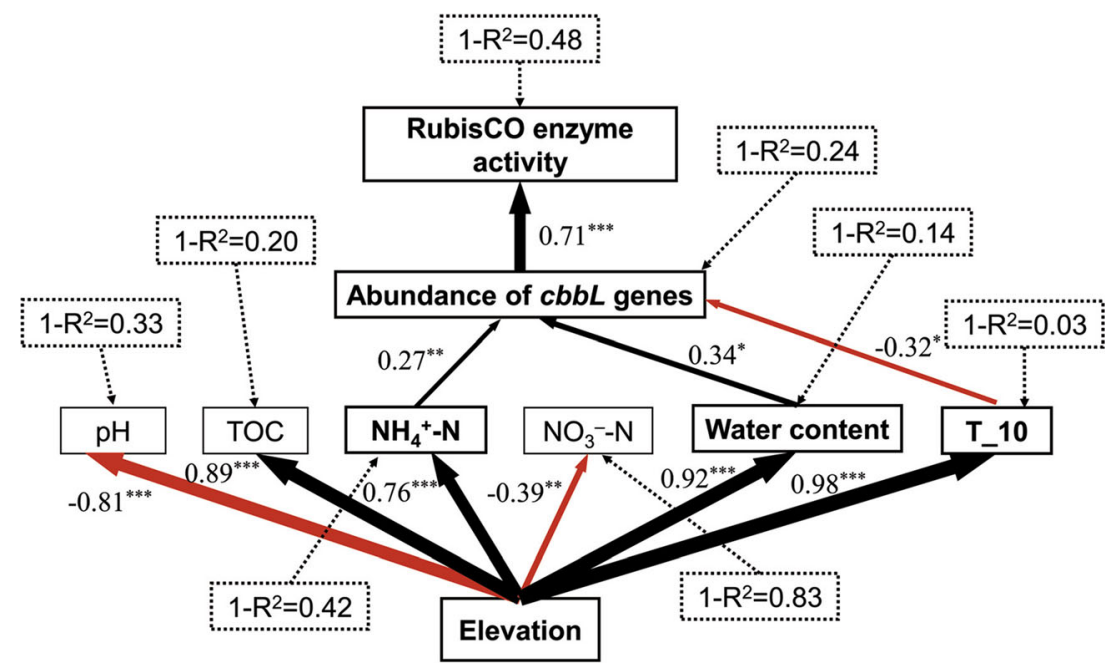

Fig. 5 Path analysis demonstrating the direct and indirect effects of elevation, soil properties, and $c b b L$ gene abundance on RubisCO enzyme activity. The numbers associated with single-headed arrows are partial regression coefficients of multiple regressions $(* * * p<0.001$, $\left.{ }^{* *} p<0.01, * p<0.05\right)$. Red and black arrows represented negative and positive correlation coefficients, respectively. The thicker line represents the higher absolute value of path coefficients. The dot-dashed rectangle represents the effect of unmeasured variables and measurement error (1$R^{2}$ ). The $c b b L$ gene abundance of forms IA/B, IC, and ID was integrated. All environmental factors, abundance, and enzyme activity were standardized by $Z$ transformation 
influenced by soil $\mathrm{pH}$ and TOC in the SEM, suggesting that autotrophs and their function are not sensitive to soil $\mathrm{pH}$, although $\mathrm{pH}$ has been regarded as one of the main drivers of soil bacterial community (Fierer and Jackson 2006; Shen et al. 2013). This is in accordance with fungi whose abundance was not affected by soil $\mathrm{pH}$, indicating the different response of various microbial groups to soil pH (Rousk et al. 2010). Taken together, our results identify that soil microbial autotroph abundance and RubisCO enzyme activity are most sensitive to water content and $\mathrm{NH}_{4}{ }^{+}$in alpine grassland soils.

The community structures of forms IC and ID dramatically changed with increasing elevations (Fig. 2), and their variation could be jointly explained by all tested factors (Table 1). It indicated that soil autotrophic microbial community structures were strongly regulated and driven by the variations of soil properties and climatic conditions resulting from elevation difference. This altitudinal distribution pattern was also exhibited in bacteria, archaea, ammonia oxidizers, and denitrifiers (Wang et al. 2015; Yang et al. 2014; Yuan et al. 2014; Zheng et al. 2014). VPA revealed a much lower individual explanation of each environmental factor to the community variation $(\leq 10.3 \%)$. This highlights the joint effects of multiple factors on soil autotrophic microbial communities, all of which play a significant role in the creation of specific ecological niches. With increasing elevations, IC and ID community structures were characterized by significant decrease or increase of dominant communities (Fig. 3 and Fig. S3). These results indicated that different microbial autotrophs responded differentially to increasing elevations for their variable genetic backgrounds and metabolic characteristics. Our results were in agreement with soil ammoniaoxidizing archaea and bacteria which demonstrated that the two groups of organisms responded very differently to land use, soil type, and climate factors (Yao et al. 2013). The different response to elevation suggest a niche differentiation in autotrophic microbial communities. The niche differentiation, which has been observed in a biofilm (Mosier et al. 2015), could provide ecological insurance for microbial autotrophs under the harsh environments.

The results exhibited that form IC bacterial autotrophs with diverse metabolic versatility dominated the autotrophic microbial communities in alpine grassland soils (Fig. 1). This is in accordance with a previous study showing that the bacterial autotroph number was much higher than chromophytic algae (Yuan et al. 2012a). These bacterial autotrophs were diverse and affiliated with Rhizobiales, Burkholderiales, and Actinomycetales. Some of the bacterial autotroph lineages observed in the current study were similar to those detected in agricultural soils, e.g., Rhizobiales and Burkholderiales, while Actinomycetales abundantly observed in the alpine grassland soils did not occur in agricultural soils (Xiao et al. 2014a; Wu et al. 2014a). Numerous species of Actinomycetales were reported to be cold adapted and could grow at or below $0{ }^{\circ} \mathrm{C}$ and were observed in Antarctic soils (Babalola et al. 2009). Rhizobiales consisted of Bradyrhizobium, Starkeya, Rhizobium, and Mesorhizobium which were reported to degrade diverse organic matters and are typical symbiotic rhizobia that establish an $\mathrm{N}_{2}$-fixing symbiosis with its legume host soybean (Borodina et al. 2005; Gourion et al. 2011; Singh and Tabita 2010). Burkholderiales consisted of Variovorax paradoxus and Rubrivivax gelatinosus are capable of degrading diverse organic carbons including starch, cellulose, gelatin, chitin, and humic acids (Han et al. 2011; Nagashima et al. 2012; Satola et al. 2013). These results suggest that the diverse metabolic versatility could be a key strategy for these microbial autotrophs to survive in harsh environments, which allows them to successfully compete with other microorganisms for resources. Form ID autotrophic microbial community largely consisted of Heterokontophyta, containing Stephanodiscus sp. and F. crotonensis. These lineages are diverse planktonic diatoms found in freshwaters and abundant in alpine lakes (Saros et al. 2005) that adapt to the cold by adjusting membrane lipid composition (Chen et al. 2013).

In conclusion, our results for the first time revealed high levels of autotrophic microbial community abundance and their enzyme activity, and both significantly increased with increasing elevations. Soil RubisCO enzyme was only originated from microbial autotrophs, and its activity was significantly driven by soil water content, $\mathrm{NH}_{4}{ }^{+}$, and temperature. Their community structure was jointly driven by soil temperature, water content, nutrients, and plant type. This study revealed that bacterial autotrophs related to Rhizobiales, Burkholderiales, and Actinomycetales dominated the autotrophic microbial community, which might play a significant role in $\mathrm{CO}_{2}$ fixation in alpine grassland soils. In order to improve the understanding of microbial $\mathrm{CO}_{2}$ fixation in the alpine grassland soils, future efforts should be oriented toward soil incubation microcosms and ${ }^{14} \mathrm{CO}_{2}$-labeling technique. Such knowledge will help us to further assess the microbial roles in $\mathrm{CO}_{2}$ fixation and response to climate changes.

Acknowledgments This project was financially supported by the National Natural Science Foundation of China (41401287 to GG and 41471054 to WK), Chinese Academy of Sciences (KZZD-EW-TZ-14 and XDB15010203 to WK), and China Postdoctoral Science Foundation (2014 M550095 to GG and 2014M550849 to JL). We thank Dr. Tianxiang Luo for the thoughtful discussions and suggestions. Reagents for RubisCO enzyme activity assay were partially provided by Dr. Baichen Wang.

Conflict of interest The authors declare that they have no competing interests. 


\section{References}

Alfreider A, Vogt C, Geiger-Kaiser M, Psenner R (2009) Distribution and diversity of autotrophic bacteria in groundwater systems based on the analysis of RubisCO genotypes. Syst Appl Microbiol 32(2): 140-150. doi:10.1016/j.syapm.2008.11.005

Babalola OO, Kirby BM, Le Roes-Hill M, Cook AE, Cary SC, Burton SG, Cowan DA (2009) Phylogenetic analysis of actinobacterial populations associated with Antarctic Dry Valley mineral soils. Environ Microbiol 11(3):566-576. doi:10.1111/j.1462-2920.2008.01809.x

Borodina E, Cox MJ, McDonald IR, Murrell JC (2005) Use of DNAstable isotope probing and functional gene probes to investigate the diversity of methyl chloride-utilizing bacteria in soil. Environ Microbiol 7(9):1318-1328. doi:10.1111/j.1462-5822.2005.00819.x

Chen DY, Yan XJ, Xu JL, Su XL, Li LJ (2013) Lipidomic profiling and discovery of lipid biomarkers in Stephanodiscus sp. under cold stress. Metabolomics 9(5):949-959. doi:10.1007/s11306-0130515-Z

Ding YJ, Liu SY, Li J, Shangguan DH (2006) The retreat of glaciers in response to recent climate warming in western China. In: MosleyThompson E, Thompson LG (eds) Annals of glaciology, vol 43. Int Glaciological Soc, Cambridge, pp 97-105

Elsaied H, Naganuma T (2001) Phylogenetic diversity of ribulose-1,5bisphosphate carboxylase/oxygenase large-subunit genes from deep-sea microorganisms. Appl Environ Microbiol 67(4):17511765. doi:10.1128/aem.67.4.1751-1765.2001

Fierer N, Jackson RB (2006) The diversity and biogeography of soil bacterial communities. PNAS 103(3):626-631. doi:10.1073/pnas. 0507535103

Ge T, Yuan H, Zhu H, Wu X, Sa N, Liu C, Tong C, Wu J, Brookes P (2012) Biological carbon assimilation and dynamics in a flooded rice-soil system. Soil Biol Biochem 48:39-46. doi:10.1016/j. soilbio.2012.01.009

Gourion B, Delmotte N, Bonaldi K, Nouwen N, Vorholt JA, Giraud E (2011) Bacterial RuBisCO is required for efficient Bradyrhizobium/ Aeschynomene symbiosis. PLoS One 6(7), e21900. doi:10.1371/ journal.pone.0021900

Guo GX, Deng H, Qiao M, Yao HY, Zhu YG (2013a) Effect of long-term wastewater irrigation on potential denitrification and denitrifying communities in soils at the watershed scale. Environ Sci Technol 47(7):3105-3113. doi:10.1021/es304714a

Guo Q, Kelt DA, Sun Z, Liu H, Hu L, Ren H, Wen J (2013b) Global variation in elevational diversity patterns. Sci Rep 3 doi:10.1038/ srep03007

Han JI, Choi HK, Lee SW, Orwin PM, Kim J, LaRoe SL, Tg K, O’Neil J, Leadbetter JR, Lee SY, Hur CG, Spain JC, Ovchinnikova G, Goodwin L, Han C (2011) Complete genome sequence of the metabolically versatile plant growth-promoting endophyte Variovorax paradoxus S110. J Bacteriol 193(5):1183-1190. doi:10.1128/jb. 00925-10

Hart KM, Kulakova AN, Allen CCR, Simpson AJ, Oppenheimer SF, Masoom H, Courtier-Murias D, Soong R, Kulakov LA, Flanagan PV, Murphy BT, Kelleher BP (2013) Tracking the fate of microbially sequestered carbon dioxide in soil organic matter. Environ Sci Technol 47(10):5128-5137. doi:10.1021/es3050696

Janatkova K, Rehakova K, Dolezal J, Simek M, Chlumska Z, Dvorsky M, Kopecky M (2013) Community structure of soil phototrophs along environmental gradients in arid Himalaya. Environ Microbiol 15(9):2505-2516. doi:10.1111/1462-2920.12132

Jin Z, Zhuang Q, He J-S, Luo T, Shi Y (2013) Phenology shift from 1989 to 2008 on the Tibetan Plateau: an analysis with a process-based soil physical model and remote sensing data. Clim Chang 119(2):435449. doi:10.1007/s10584-013-0722-7

John DE, Wang ZA, Liu X, Byrne RH, Corredor JE, Lopez JM, Cabrera A, Bronk DA, Tabita FR, Paul JH (2007) Phytoplankton carbon fixation gene (RuBisCO) transcripts and air-sea $\mathrm{CO}_{2}$ flux in the Mississippi River plume. ISME J 1(6):517-531. doi:10.1038/ ismej. 2007.70

Kong WD, Ream DC, Priscu JC, Morgan-Kiss RM (2012a) Diversity and expression of RubisCO genes in a perennially ice-covered Antarctic lake during the polar night transition. Appl Environ Microbiol 78(12):4358-4366. doi:10.1128/aem.00029-12

Kong WD, Dolhi JM, Chiuchiolo A, Priscu J, Morgan-Kiss RM (2012b) Evidence of form II RubisCO $(c b b M)$ in a perennially ice-covered Antarctic lake. FEMS Microbiol Ecol 82(2):491-500. doi:10.1111/j. 1574-6941.2012.01431.x

Lukow T, Dunfield PF, Liesack W (2000) Use of the T-RFLP technique to assess spatial and temporal changes in the bacterial community structure within an agricultural soil planted with transgenic and non-transgenic potato plants. FEMS Microbiol Ecol 32(3): 241-247

Lutz AF, Immerzeel WW, Shrestha AB, Bierkens MFP (2014) Consistent increase in High Asia's runoff due to increasing glacier melt and precipitation. Nat Clim Chang 4:587-592. doi:10.1038/ nclimate 2237

Miltner A, Richnow HH, Kopinke FD, Kastner M (2004) Assimilation of $\mathrm{CO}_{2}$ by soil microorganisms and transformation into soil organic matter. Org Geochem 35(9):1015-1024. doi:10.1016/j. orggeochem.2004.05.001

Mosier AC, Li Z, Thomas BC, Hettich RL, Pan C, Banfield JF (2015) Elevated temperature alters proteomic responses of individual organisms within a biofilm community. ISME J 9:180-194. doi:10. 1038/ismej.2014.113

Nagashima S, Kamimura A, Shimizu T, Nakamura-Isaki S, Aono E, Sakamoto K, Ichikawa N, Nakazawa H, Sekine M, Yamazaki S, Fujita N, Shimada K, Hanada S, Nagashima KVP (2012) Complete genome sequence of phototrophic Betaproteobacterium Rubrivivax gelatinosus IL144. J Bacteriol 194(13):3541-3542. doi:10.1128/jb.00511-12

Nanba K, King GM, Dunfield K (2004) Analysis of facultative lithotroph distribution and diversity on volcanic deposits by use of the large subunit of ribulose 1,5-bisphosphate carboxylase/oxygenase. Appl Environ Microbiol 70(4):2245-2253. doi:10.1128/aem.70.4.22452253.2004

Nogues-Bravo D, Araujo MB, Romdal T, Rahbek C (2008) Scale effects and human impact on the elevational species richness gradients. Nature 453(7192):216-219, http://www.nature.com/nature/journal/ v453/n7192/suppinfo/nature06812 S1.html

Paul JH, Alfreider A, Kang JB, Stokes RA, Griffin D, Campbell L, Ornolfsdottir E (2000) Form IA $r b c L$ transcripts associated with a low salinity/high chlorophyll plume ('Green River') in the eastern Gulf of Mexico. Mar Ecol Prog Ser 198:1-8. doi:10.3354/ meps 198001

Ren W, Tan HC, Wu J, Deng YC, Wu YB, Tang YH, Cui XY (2010) UV light spectral response of photosynthetic photochemical efficiency in alpine mosses. J Plant Ecol 3(1):17-24. doi:10.1093/jpe/rtp029

Rousk J, Baath E, Brookes PC, Lauber CL, Lozupone C, Caporaso JG, Knight R, Fierer N (2010) Soil bacterial and fungal communities across a $\mathrm{pH}$ gradient in an arable soil. ISME J 4(10):1340-1351. doi: 10.1038/ismej.2010.58

Saros JE, Michel TJ, Interlandi SJ, Wolfe AP (2005) Resource requirements of Asterionella formosa and Fragilaria crotonensis in oligotrophic alpine lakes: implications for recent phytoplankton community reorganizations. Can J Fish Aquat Sci 62(7):1681-1689. doi:10. 1139/f05-077

Satola B, Wübbeler J, Steinbüchel A (2013) Metabolic characteristics of the species Variovorax paradoxus. Appl Microbiol Biotechnol 97(2):541-560. doi:10.1007/s00253-012-4585-Z

Schloss PD, Westcott SL, Ryabin T, Hall JR, Hartmann M, Hollister EB (2009) Introducing mothur: open source, platform-independent, community-supported software for describing and comparing 
microbial communities. Appl Environ Microbiol 75:7537-7541. doi:10.1128/aem.01541-09

Selesi D, Schmid M, Hartmann A (2005) Diversity of green-like and redlike ribulose-1,5-bisphosphate carboxylase/oxygenase large-subunit genes $(c b b L)$ in differently managed agricultural soils. Appl Environ Microbiol 71(1):175-184. doi:10.1128/aem.71.1.175-184.2005

Shen C, Xiong J, Zhang H, Feng Y, Lin X, Li X, Liang W, Chu H (2013) Soil $\mathrm{pH}$ drives the spatial distribution of bacterial communities along elevation on Changbai Mountain. Soil Biol Biochem 57:204-211. doi:10.1016/j.soilbio.2012.07.013

Shen MG, Zhang GX, Cong N, Wang SP, Kong WD, Piao SL (2014) Increasing altitudinal gradient of spring vegetation phenology during the last decade on the Qinghai-Tibetan Plateau. Agric For Meteorol 189:71-80. doi:10.1016/j.agrformet.2014.01.003

Shipley B (2000) Cause and correlation in biology: a user's guide to path analysis, structural equations, and causal inference. Cambridge University Press, Cambridge

Singh J, Tabita FR (2010) Roles of RubisCO and the RubisCO-like protein in 5-methylthioadenosine metabolism in the nonsulfur purple bacterium Rhodospirillum rubrum. J Bacteriol 192(5):1324-1331. doi:10.1128/jb.01442-09

Su YG, Wu L, Zhou ZB, Liu YB, Zhang YM (2013) Carbon flux in deserts depends on soil cover type: a case study in the Gurbantunggute desert, north China. Soil Biol Biochem 58:332340. doi:10.1016/j.soilbio.2012.12.006

Tabita FR, Satagopan S, Hanson TE, Kreel NE, Scott SS (2008) Distinct form I, II, III, and IV Rubisco proteins from the three kingdoms of life provide clues about Rubisco evolution and structure/function relationships. J Exp Bot 59(7):1515-1524. doi:10.1093/jxb/erm361

Takai K, Campbell BJ, Cary SC, Suzuki M, Oida H, Nunoura T, Hirayama H, Nakagawa S, Suzuki Y, Inagaki F, Horikoshi K (2005) Enzymatic and genetic characterization of carbon and energy metabolisms by deep-sea hydrothermal chemolithoautotrophic isolates of Epsilonproteobacteria. Appl Environ Microbiol 71(11): 7310-7320. doi:10.1128/aem.71.11.7310-7320.2005

Tamura K, Stecher G, Peterson D, Filipski A, Kumar S (2013) MEGA6: molecular evolutionary genetics analysis version 6.0. Mol Biol Evol 30(12):2725-2729. doi:10.1093/molbev/mst197

Tan KH (2005) Soil sampling, preparation and analysis. CRC Press, Boca Raton

Thomas EK, Huang Y, Morrill C, Zhao J, Wegener P, Clemens SC, Colman SM, Gao L (2014) Abundant C-4 plants on the Tibetan Plateau during the Lateglacial and early Holocene. Quat Sci Rev 87:24-33. doi:10.1016/j.quascirev.2013.12.014

Tolli J, King GM (2005) Diversity and structure of bacterial chemolithotrophic communities in pine forest and agroecosystem soils. Appl Environ Microbiol 71(12):8411-8418. doi:10.1128/ aem.71.12.8411-8418.2005

Vetaas OR, Grytnes J-A (2002) Distribution of vascular plant species richness and endemic richness along the Himalayan elevation gradient in Nepal. Glob Ecol Biogeogr 11(4):291-301. doi:10.1046/j. 1466-822X.2002.00297.x

Videmšek U, Hagn A, Suhadolc M, Radl V, Knicker H, Schloter M, Vodnik D (2009) Abundance and diversity of $\mathrm{CO}_{2}$-fixing bacteria in grassland soils close to natural carbon dioxide springs. Microb Ecol 58(1):1-9. doi:10.1007/s00248-008-9442-3

Wang B, Bao Q, Hoskins B, Wu G, Liu Y (2008) Tibetan plateau warming and precipitation changes in East Asia. Geophys Res Lett 35(14). doi:10.1029/2008g1034330

Wang Y, Julio Camarero J, Luo T, Liang E (2012) Spatial patterns of Smith fir alpine treelines on the south-eastern Tibetan Plateau support that contingent local conditions drive recent treeline patterns.
Plant Ecolog Divers 5(3):311-321. doi:10.1080/17550874.2012. 704647

Wang Z, Luo T, Li R, Tang Y, Du M (2013) Causes for the unimodal pattern of biomass and productivity in alpine grasslands along a large altitudinal gradient in semi-arid regions. J Veg Sci 24(1): 189-201. doi:10.1111/j.1654-1103.2012.01442.x

Wang JT, Cao P, Hu HW, Li J, Han LL, Zhang LM, Zheng YM, He JZ (2015) Altitudinal distribution patterns of soil bacterial and archaeal communities along Mt. Shegyla on the Tibetan Plateau. Microb Ecol 69(1):135-145. doi:10.1007/s00248-014-0465-7

Wu X, Ge T, Yuan H, Li B, Zhu H, Zhou P, Sui F, O’Donnell AG, Wu J (2014a) Changes in bacterial $\mathrm{CO}_{2}$ fixation with depth in agricultural soils. Appl Microbiol Biotechnol 98(5):2309-2319. doi:10.1007/ s00253-013-5179-0

Wu X, Ge T, Yuan H, Zhou P, Chen X, Chen S, Brookes P, Wu J (2014b) Evaluation of an optimal extraction method for measuring dribulose-1,5-bisphosphate carboxylase/oxygenase (RubisCO) in agricultural soils and its association with soil microbial $\mathrm{CO}_{2}$ assimilation. Pedobiologia 57(4-6):277-284. doi:10.1016/j.pedobi.2014.06. 002

Xiao KQ, Bao P, Bao QL, Jia Y, Huang FY, Su JQ, Zhu YG (2014a) Quantitative analyses of ribulose-1,5-bisphosphate carboxylase/ oxygenase (RubisCO) large-subunit genes $(c b b L)$ in typical paddy soils. FEMS Microbiol Ecol 87(1):89-101. doi:10.1111/1574-6941. 12193

Xiao KQ, Nie SA, Bao P, Wang FH, Bao QL, Zhu YG (2014b) Rhizosphere effect has no effect on marker genes related to autotrophic $\mathrm{CO}_{2}$ fixation in paddy soils? J Soils Sediments 14(6):10821087. doi:10.1007/s11368-014-0864-x

Xu HH, Tabita FR (1996) Ribulose-1,5-bisphosphate carboxylase/ oxygenase gene expression and diversity of Lake Erie planktonic microorganisms. Appl Environ Microbiol 62(6):1913-1921

Yang Y, Gao Y, Wang S, Xu D, Yu H, Wu L, Lin Q, Hu Y, Li X, He Z, Deng Y, Zhou J (2014) The microbial gene diversity along an elevation gradient of the Tibetan grassland. ISME J 8(2):430-440. doi: 10.1038/ismej.2013.146

Yao HY, Campbell CD, Chapman SJ, Freitag TE, Nicol GW, Singh BK (2013) Multi-factorial drivers of ammonia oxidizer communities: evidence from a national soil survey. Environ Microbiol 15(9): 2545-2556. doi:10.1111/1462-2920.12141

Yuan HZ, Ge TD, Chen CY, O'Donnell AG, Wu JS (2012a) Significant role for microbial autotrophy in the sequestration of soil carbon. Appl Environ Microbiol 78(7):2328-2336. doi:10.1128/aem. 06881-11

Yuan HZ, Ge TD, Wu XH, Liu SL, Tong CL, Qin HL, Wu MN, Wei WX, Wu JS (2012b) Long-term field fertilization alters the diversity of autotrophic bacteria based on the ribulose-1,5-biphosphate carboxylase/oxygenase (RubisCO) large-subunit genes in paddy soil. Appl Microbiol Biotechnol 95(4):1061-1071. doi:10.1007/ s00253-011-3760-y

Yuan Y, Si G, Wang J, Luo T, Zhang G (2014) Bacterial community in alpine grasslands along an altitudinal gradient on the Tibetan Plateau. FEMS Microbiol Ecol 87(1):121-132. doi:10.1111/15746941.12197

Zhang LM, Wang M, Prosser JI, Zheng YM, He JZ (2009) Altitude ammonia-oxidizing bacteria and archaea in soils of Mount Everest. FEMS Microbiol Ecol 70(2):208-217. doi:10.1111/j.1574-6941. 2009.00775.X

Zheng Y, Yang W, Hu H-W, Kim YC, Duan JC, Luo CY, Wang SP, Guo LD (2014) Ammonia oxidizers and denitrifiers in response to reciprocal elevation translocation in an alpine meadow on the Tibetan Plateau. J Soils Sediments 14(6):1189-1199. doi:10.1007/s11368014-0867-7 